\title{
A LABORATORY STUDY FOR THE CHARACTERIZATION AND TREATMENT OF AN ARCHAEOLOGICAL RIFLE FROM DHAMAR MUSEUM, YEMEN
}

\author{
Ali, N. \& Megahed, M. \\ Conservation dept., Faculty of Archaeology, Fayoum Univ., Fayoum, Egypt.
}

E-mail:nmaoo@fayoum.edu.eg

\begin{abstract}
A rifle and its ammunition pouch, from Dhamar museum, Yemen, were selected for the study. While the rifle was made of iron and wood, its ammunition pouch was taken from an animal horn. Both are considered an artifcat.This composite structure, consisted, due to its complex nature, of more than one element, where each element tended to influence and be influenced mutually by one or more of the other's elements. Hence, the current study aimed to examine the rifle and its ammunition pouch, as follows: studying metal corrosion; examining the wood, horn, and their deterioration phenomena; and explaining the mutual impact of the different materials. This helps us understand the serious problems of the corrosive phenomena and their degradation mechanisms. It also helps identify their structure in order to provide the scientific treatment and conservation of the organic parts (Tamarix, Syacamore wood and animal Horn), and inorganic parts (Iron and cupper). Therefore, samples from the rifle and its ammunition pouch were taken and examined by Light Microscope, Metallographic Microscope, Scanning Electron Microscope, X-Ray Diffraction, and X-Ray Fluorescence. Accordingly, chemical cleaning was chosen for treatment (by Alcohol and Toluene for wood and citric acid for metal parts).
\end{abstract}

Keywords: Composite artifacts, Wood, Iron, Horn, deterioration, Corrosion, Surface cleaning, Consolidation

\section{Introduction}

The conservation of composite artifcats, especially those made of wood as organic material with iron as inorganic material, and iron with animal horn faces serious problems, due to their composite nature because each element tends to influence and be influenced by one or more of the other elements [1]. Wood cell has a complex structure [2]. As an organinc material, it is composed of carbohydrate components, e.g. cellulose, hemicellulose, and lignin [3], which were affected by heat and environmen-tal factors. Horn is made of an animal source. Finally, the iron body and the copper wire are inorganic materials. The problem of treating this object of composite structure is because of the mutual effects of wood and horn, as organic porous mat-erials, and iron, as an inorganic mate-rial. For example, wood, when exposed to moisture, absorbs some water through the hygroscopic property, which causes the growth of microorganisms, as well as diluting a part of the carbohydrates present in wood, changing wood color, but iron and copper are corroded by oxygen in the pres-ence of moisture, forming rust. Rust 
is a term used to describe non-specific corrosion products which make a layer on the surface of degraded iron in addition to the corrosion of copper wire that tends to accelerate corrosion of the metal by forming localized corrosion cells. A variety of iron oxides and hydroxides can form, depending on the $\mathrm{pH}$, oxygen concentration, relative humidity, and contamination. Moreover, chloride ions "Cl- ions" can be attracted to the buried iron in the surrounding soil. When the iron artifacts are buried in the soil, they would be exposed to corrosion, forming iron rust, by highly complicated series of processes that get mixed with dirt in soil. In fact, the corrosion process is not a chemical reaction, but it is an electrochemical reaction [4]. In regard to the corrosion of iron in soil, there are two major causes, namely the acidification of the soil and water levels in ground, besides soil composition of the deteriorated organic and inorganic materials together $[5,6]$. Iron will be passive if the $\mathrm{pH}$ at the metal surface rises above 10 and will not be corroded. However, it is not for sure that the $\mathrm{pH}$ at the metal surface rises to 10 since hydroxide ions diffusing at the surface will precipitate by the iron ions. Additionally, hydrogen evolution at the metal will not occur fast enough to affect the $\mathrm{pH}$ noticeably. Even if this $\mathrm{pH}$ rise does occur, it is unlikely that passivity will result, for several reasons. Firstly, experimental passivation potentials are much higher (approx. Ov at $\mathrm{pH}$ 10), than those measured. Secondly, inhibition by hydroxide is due to the formation of $\mathrm{Fe}_{2} \mathrm{O}_{3}$ film on the surface. This usually requires the presence of oxygen on the surface [7]. The corrosion of archaeological metals continues after excavation. Then, the careful use of a suitable treatment is, therefore, necessary to preserve the material and the scientific value that the artifacts carry. Cleaning is the first step in conservation. It is also the most difficult process in the treatment of metal objects. Cleaning has to begin taking into account the object's form, function, and material $[8,9]$. It could be concluded that there are many reactions that may occur between wood, as an organic material, and iron, as an inorganic material. These reactions can absorb moisture from the air or soil, conveying it to iron and copper, causing rust or a corrosion layer. However, iron and copper can change part of the rust or corrosion across the pores of the wood causing the dark color of the rifle's wood. The same reaction can occur between iron and animal horn in the rifle ammunition pouch $[10,11]$. The objective of the study is to identify the morphology of wood and metals, recognize the metal parts of this Ottoman rifle, study the mechanism of deterioration, and prevent its occurrence in the future.

\section{Materials and Methods}

\subsection{Description and condition of the rifle and its ammunition pouch}

It is a rifle that belongs to the Ottoman period in the collections of Dhamar Museum, Yemen. It is made of iron and wood, and there are 8 rings of copper strips, connecting the iron parts with wood. It is $148 \mathrm{~cm}$ long, with a muzzle diameter of $1.2 \mathrm{~cm}$. Its back part is rectangular of $14 \times 6 \mathrm{~cm}$. The rifle shows many manifestations of deterioration such as corrosion of the iron parts and dirt and micro-cracks on the wooden part. The second object is the ammunition pouch, which is a big, hollow, made of an animal horn, with a cover made of iron. It is length is $36 \mathrm{~cm}$, and its diameter sloping from $10 \mathrm{~cm}$ at the opening, to $2.5 \mathrm{~cm}$ at the end. It suffered from damage, such as corrosion in the iron parts and dirt and disco-loration on the wooden parts and the animal horn, fig. (1-a, b, c). 

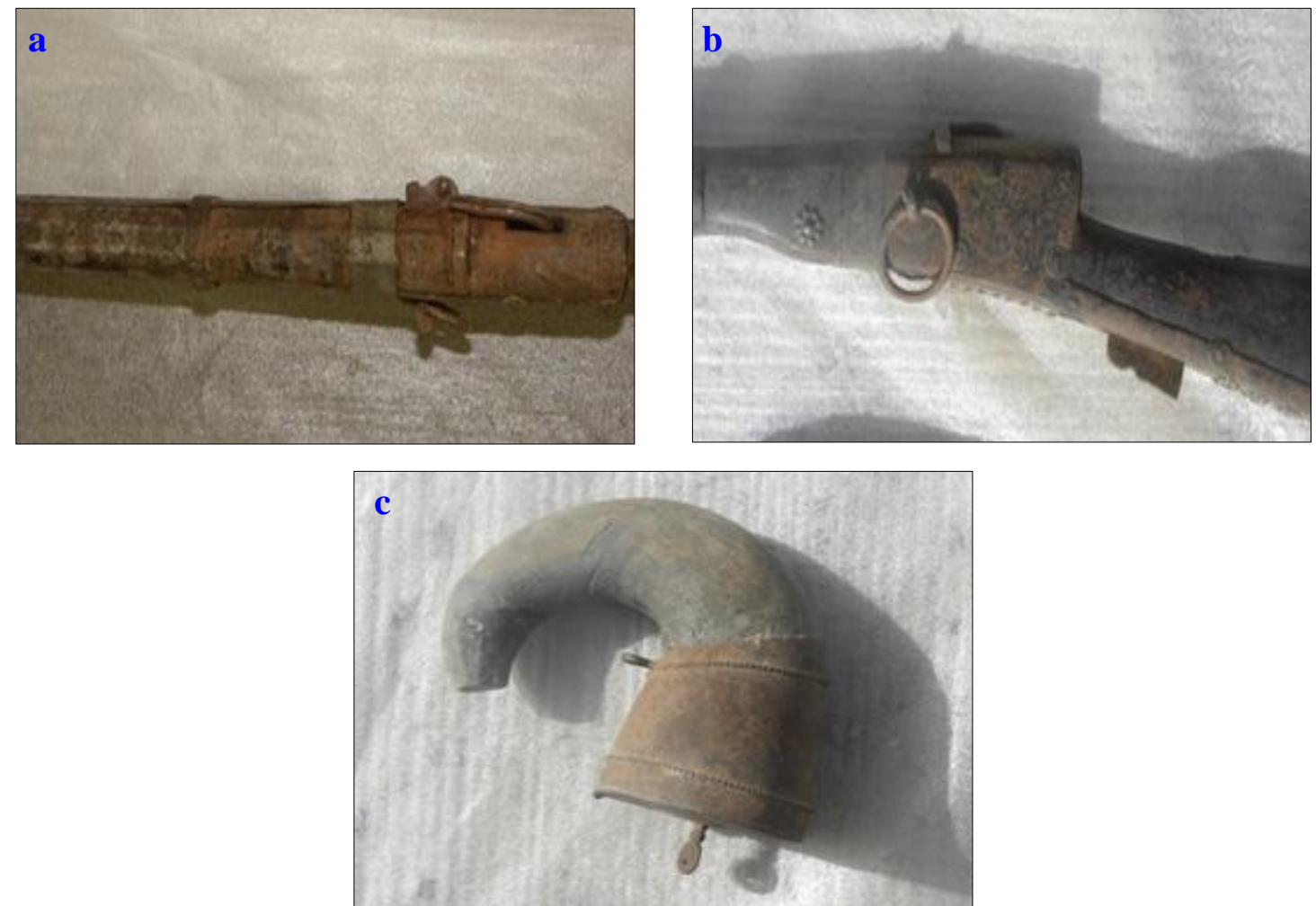

Figure (1) Shows different parts of the rifle before the treatment $\underline{\mathbf{a}}$. the front part, $\underline{\mathbf{b}}$. the back part, $\underline{\mathbf{c}}$. the ammunition pouch

\subsection{Methods of examination and analysis}

Analyses used in the samples taken from the rifle and their ammunition pouches (iron, copper, wood, and animal horn) were conducted using many devices, as follows: Light microscope with a camera was used to examine wood slides; this examination helped us to identify wood gens. Metallographic examination was used to identify the problems in the metallic parts of the rifle and the ammunition pouch. A sample from the rifle was analyzed using $X-R D$ to identify

\section{Results}

\subsection{Light microscope}

The microscope examination showed that the rifle's wood belonged to two kinds of wood, the rifle's front parts, Tamarix Tetrandra, where a cross section of tamarix showed ring boundaries growth is distinct by the difference in the vessel size, fig. (2-a, b)[12]. It is an evergreen high shrub that grows in sandy the deterioration of the rifle's metal parts and to help us in the treatment of the composite object. X-Ray Florescence analysis was used to analyze two small samples taken from the rifle and their ammunition pouch. Furthermore, SEM photomicrograph was captured to evaluate the deterioration spots on the rifle and its ammunition pouch. Furthermore, EDX was adapted to investigate the elements of the sample.

and salty deserts and wadi [13]. The second kind of wood was Syacamore Ficus was at the back of the rifle. The cross section showed that growth rings were absent and vessels were diffused, with a tangential diameter of 90-240 $\mu \mathrm{m}$ and a radial diameter up to $300 \mu \mathrm{m}$, as shown in fig. (2-c, d) [14]. 

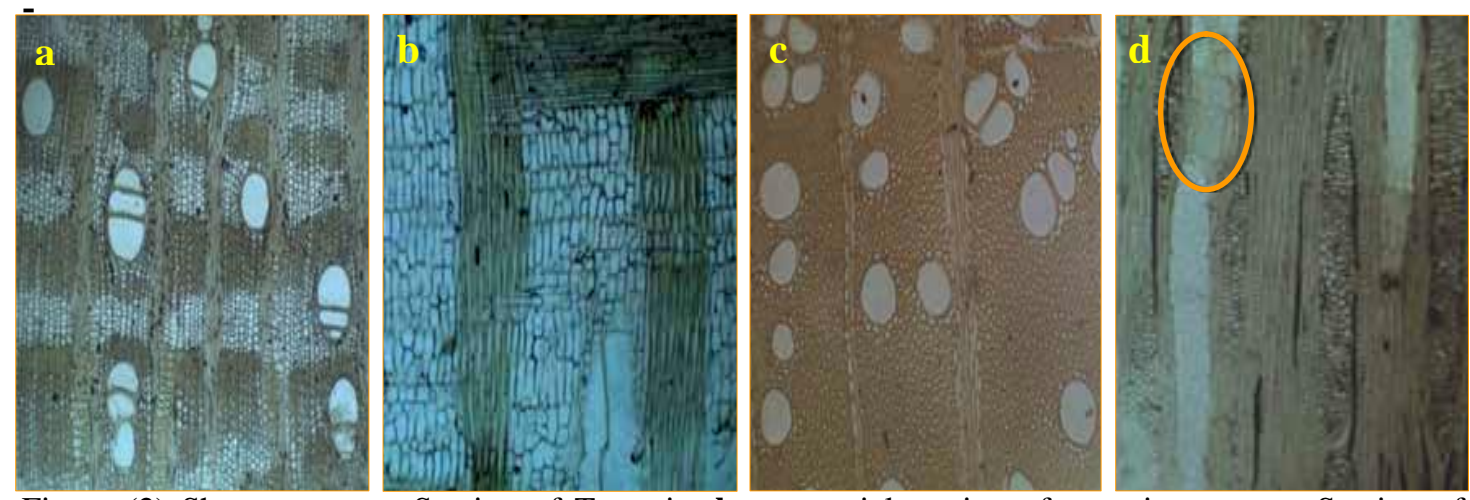

Figure (2) Shows a $\underline{\mathbf{a}}$. cross Section of Tamarix, $\underline{\mathbf{b}}$. tangential section of tamarix, $\underline{\mathbf{c}}$. cross Section of Syacamore, $\underline{\mathbf{d}}$. tangential section of Syacamore.

\subsection{Metallographic examination}

Metallographic examination of the metallic parts of the rifle and the ammunition pouch showed that micro

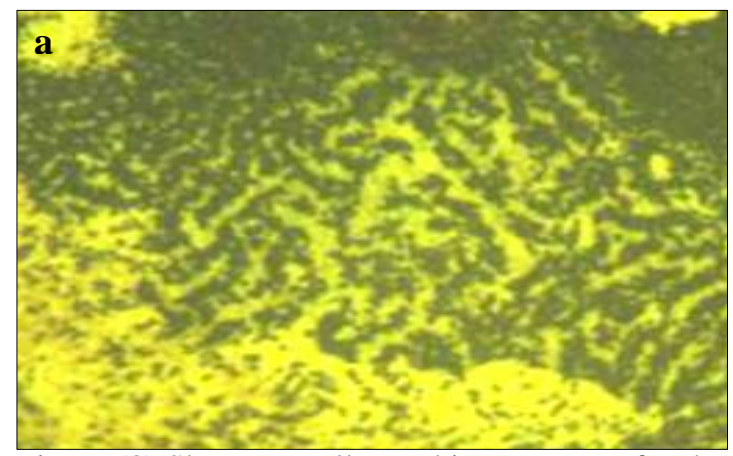

cracks and pitting corrosion spread on the surface, fig. (3-a, b).

Figure (3) Shows metallographic capture a. for the rifle showing the micro structure of the metal on the surface, $\underline{\mathbf{b}}$. for the surface of ammunition pouch showing pitting corrosion and micro cracks dispersed

\subsection{X-Ray fluorescence analysis}

$\mathrm{X}$-ray Fluorescence analytical data of the corrosion elements of the rifle and the cover of the ammunition

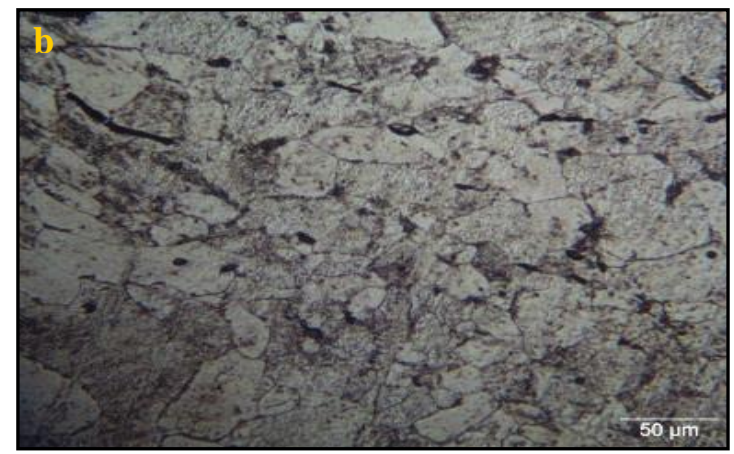

Table (1) X-R Fluorescence Analysis of the rifle and the cover of the ammunition pouch

\begin{tabular}{lccccccc}
\multicolumn{1}{c}{ Elements } & \multicolumn{7}{c}{ Analytical Ratios \% } \\
& $\boldsymbol{F e}$ & $\boldsymbol{S i}$ & $\boldsymbol{S n}$ & $\boldsymbol{Z n}$ & $\boldsymbol{A S}$ & $\boldsymbol{O}$ & Total \\
The rifle & 96.26 & 3.74 & - & - & - & - & 100 \\
The metal part in the ammunition pouch (cover) & 93.31 & - & - & - & - & 6.69 & 100 \\
\hline
\end{tabular}

\subsection{XRD analysis}

A sample from corrosion stuff on the rifle was taken and analyzed using a Philips X-ray Diffractometer with $\mathrm{Cu}$ Karadiation. The aim of this analysis was to identify the corrosion compounds in order to decide whether

pouch showed that the rifle composed mainly of some elements with different ratios as listed in table (1).

Table (1) XRD analysis of the rifle corrosion products

\begin{tabular}{cccc}
\hline Samples & Major Minerals & Minor Minerals & Trace Minerals \\
\hline \multirow{2}{*}{ Rifle corrosion } & Tephroite $\left[\mathrm{Mn}_{2} \mathrm{SiO}_{4}\right]$ & Quartz $\left[\mathrm{SiO}_{2}\right]$ & $\begin{array}{c}\text { Potassium Iron Hydgen } \\
\text { Phosphate }\end{array}$ \\
& & & {$\left[\mathrm{K} \mathrm{Fe} \mathrm{H}_{14}\left(\mathrm{PO}_{4}\right) 8.4 \mathrm{H}_{2} \mathrm{O}\right]$} \\
\hline
\end{tabular}




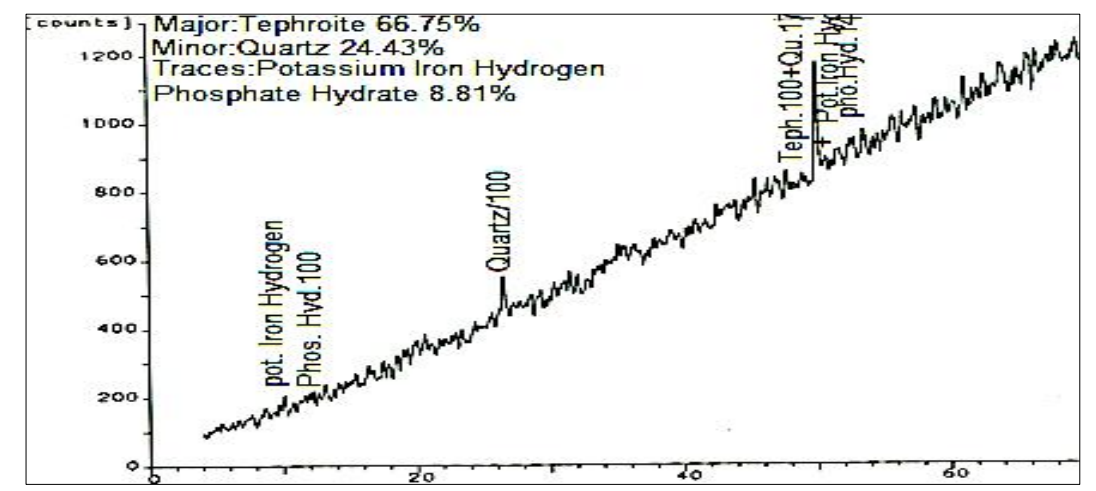

Figure (4) Shows XRD pattern of the corrosion products of the rifle

\subsection{SEM investigations and EDX analysis}

SEM investigations of the wooden part in the Ottoman rifle showed the presence of rust between wooden structures. Where, the rifle's ammunition pouch, (the horn) showed rust between the pouch grains, and the presence of rust was less between wood fibers. In addition, the metal parts showed the microstructure of deterioration spots, all of these features

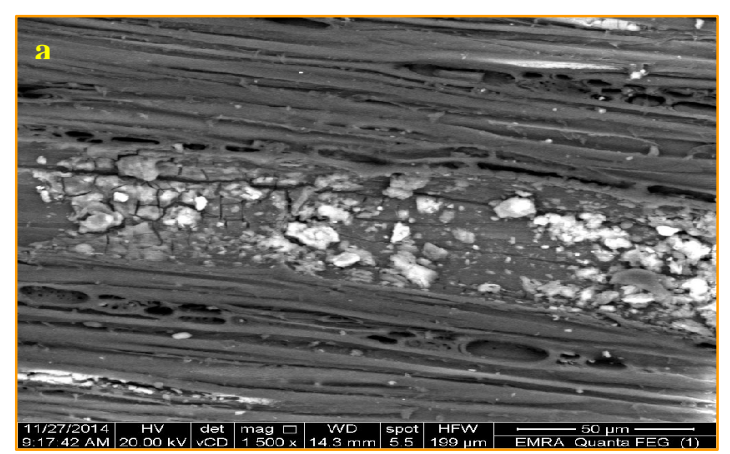

are shown in fig. (5-a, b, c). EDX analysis proved that the structure of the horn consisted mainly of $(\mathrm{C}, \mathrm{O}, \mathrm{Na}, \mathrm{Mg}, \mathrm{Fe}$, $\mathrm{Al}, \mathrm{S}, \mathrm{Si}, \mathrm{Cl}$, and $\mathrm{K})$. Therefore, (Fe and $\mathrm{O})$ were the elements of rust corrosion, ( $\mathrm{Si}, \mathrm{Al}, \mathrm{Mg}$, and $\mathrm{K}$ ) were the elements of dirt and $(\mathrm{Na}$ and $\mathrm{Cl})$ were the elements of Halite salt, fig. (5-d).
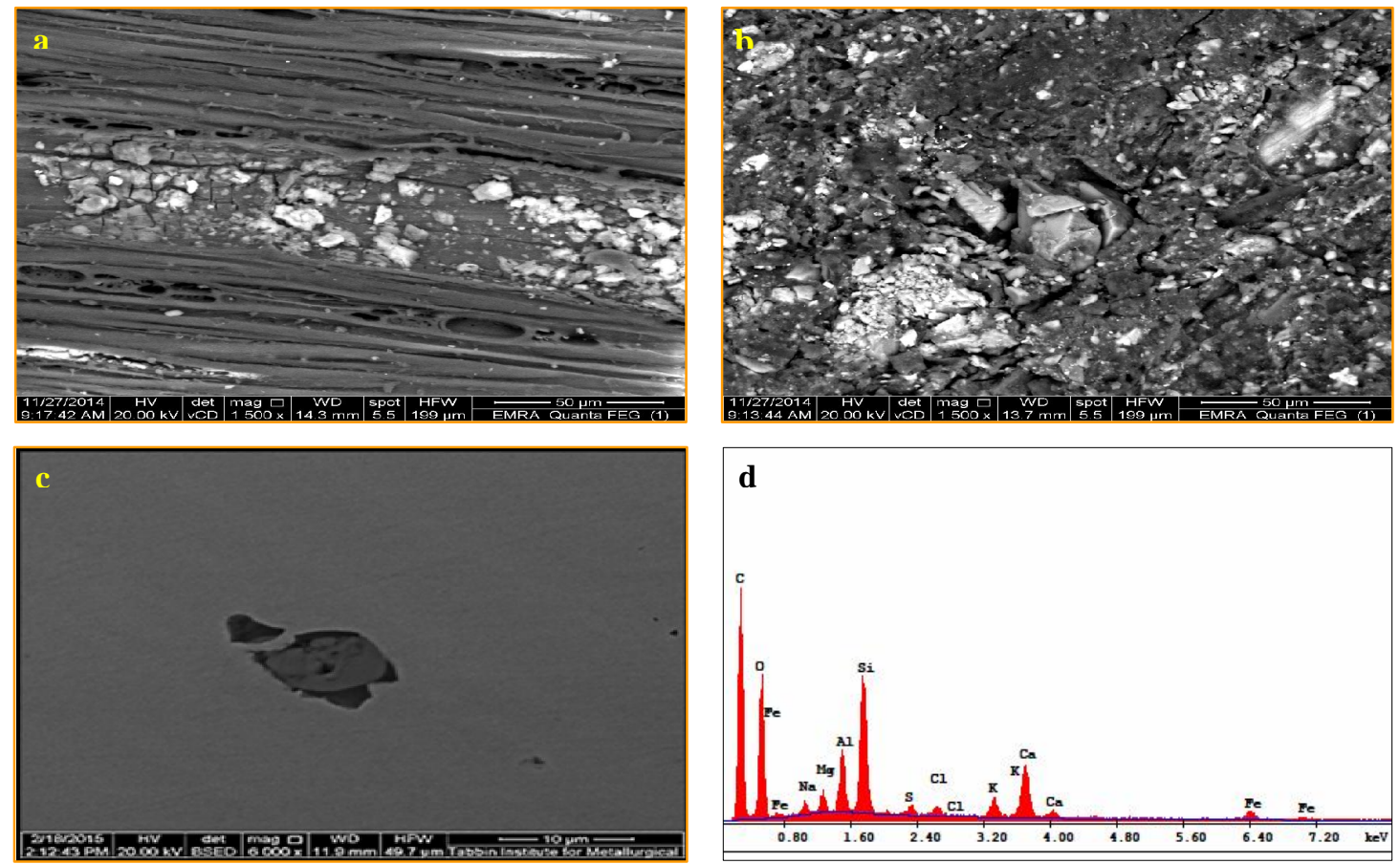

Figure (5) Shows SEM photomicrographs of the rifle a. the existence of rust between wood fibers X$1500, \underline{\mathbf{b}}$. the existence of rust between horn grains $X-1500$, $\underline{\mathbf{c}}$. pitting corrosion and disturbing the of the metal of the ammunition pouch $\underline{\mathbf{d}}$. EDX analysis of the horn structure that consisting of (C,O, $\mathrm{Na}, \mathrm{Mg}, \mathrm{Fe}, \mathrm{Al}, \mathrm{S}, \mathrm{Si}, \mathrm{Cl} \& \mathrm{~K})$

\section{Treatment and Conservation}

Due to containing the rifle and its ammunition pouch different composite matters (wood-horn-iron-copper); each part was treated separately with different methods and materials. Where, the using

of suitable materials for organic materials is not effective on inorganic ones or metals. Within the same context, using of acid and alkaline solutions might cause damage to the wood and horn. In our case, mecha- 
nical cleaning was used in a limited area because the rust was a thin layer but it was acceptable after making a test on a replica and in hidden parts with selected solutions. Then, the chemical cleaning was performed on some wooden parts. Here, the rifle and its ammunition pouch were mechanically cleaned, first. Then, the chemical cleaning was performed on some wooden parts that were separated to save them from acids and alkaline solutions. Chemical cleaning of the wood was inclu-ded using some mixed solution of (1 Alcohol: 1 Toluene) to remove the rest of the rust layer which damaged the surface of wood and horn. Wood and horn consolidation was an important process. Regalerz 1094 was very suitable for brittle wood and horn; this polymer was diluted in toluene of $5 \%$ concentration which was applied with injection technique. The organic parts were left for 48 hours until they were dry in the ambient air. After that, the surface was covered with a thin layer of $2 \%$ Regalerz in Toluene. To clean iron objects, dirt, grease and loose or flaking rust must be removed before applying protective coatings. Such deposits can be removed using chemical or mechanical techniques. Chemical cleaning include using soapy solutions to dissolve grease and remove surface dirt. For example, aqueous alkaline solution (caustic soda) was used to remove grease and paint. Concentrations in the range of 20-40 g. of sodium hydroxide per liter of water are normally used. Corrosion products can be removed using a solution of $50 \mathrm{~g}$. of citric acid in water. While citric acid is relatively safe on most objects, care should be taken to ensure that cast iron, cast steel or spring steel, or combinations of them are not left unattended for long periods because they will actively corrode. Prolonged gas evolution (which you will be seen as bubbling) indicates that the iron surface is corroding. With harder alloys, this can also cause hydrogen embitterment in which hydrogen is generated within the metal and the stress of the gas pressure cracks it. Gas evolution can also result in pitted, weakened or destroyed objects. Simple wire brushing can be used. There is doubt regarding the type of iron or the duration of acid treatment, more time should be spent removing corrosion products by mechanical means. Once the worst deposits are removed, short treatment in citric acid should clean the object, with reduced risk of damage. Some forms of corrosion leave spots on the object, which cannot be removed by citric acid and can be mechanically removed. On treating large objects, it is difficult to find large enough containers or tubes to immerse the objects for caustic or citric treatments. If sand blasting is inappropriate, the acid or alkaline stripping solution can be applied to the surface using a bentonite paste or absorbed cotton. Finally, washing the object by deionized water, which should be repeated perfectly to ensure flushing capillaries to remove any chemical residues. Then, soft and clean cloth is used for drying. Coating the rifle and the storage with $3 \%$ solution of Benzotriazole (BTA) soluble in Ethanol, fig. (6-a, b, c).

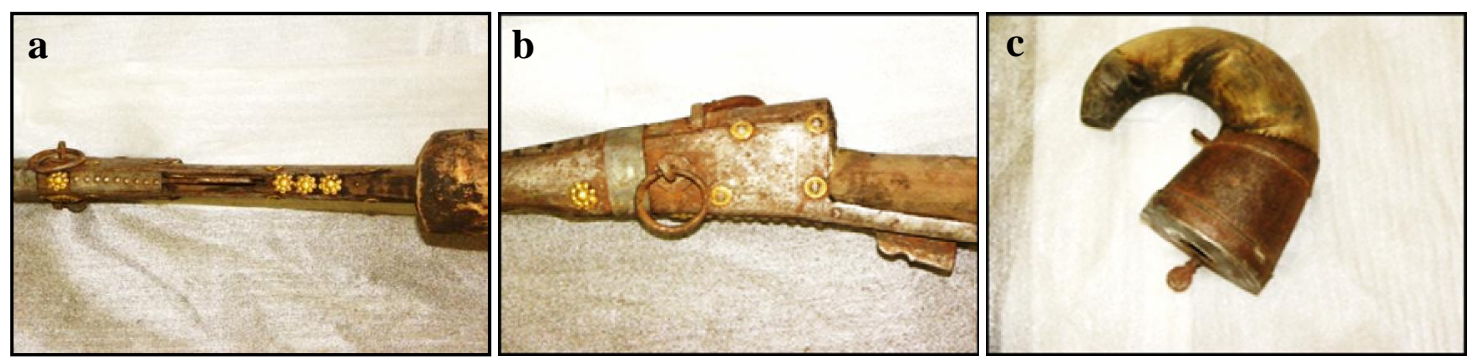

Figure (5) Shows $\underline{\mathbf{a}} . \& \underline{\mathbf{b}}$. the back part of the rifle, $\underline{\mathbf{c}}$. the ammunition pouch after the treatment after the treatment

\section{Discussion}

Light microscope examination showed that the rifle's wood belonged to two kinds of wood. The first kind was Tamarix tetrandra (Desert Tamarisk) that 
was in the front part of rifle. In the cross section, growth rings were pale to discrete. Rays distended tangentially in the boundary amidst them. Wood diffuse-to semi-ringporous diameter of vessels was 20-50 $\mathrm{mm}$, mostly solitary and rounded. Gums and other deposits in heart-wood vessels. Inter-vessel pits interchange. Pits of the neighboring vessels played a major role in the entry of air and water meniscus from the embolised vessel [15], also, the intra-annual density variations [16]. In the tangential section, there were larger rays that are commonly 4 to 10 seriate. Axial parenchyma and vessel elements storied. The second kind was Syacamore Ficus that was in the back part of the rifle. These two kinds grow in Egypt and adjacent areas. So, this rifle might be made in Egypt in the Ottoman period. This kind of wood had many identikits. The cross-section shows that growth rings were absent, marked only by gradual change in the width of parenchyma. Vessels were diffuse, rarely solitary, and rounded with a redial diameter up to $300 \mu \mathrm{m}$. The vessel length was $490 \mu \mathrm{m}$. Inter- vessel pits were alternate, round to polygonal of 7-9 $\mu \mathrm{m}$ and fibers were thin to thick-walled. There were compression wood. Axial parenchyma often banded more than three cells wide. Rays were $4-12$ per $\mathrm{mm}$. In the tangential section, there were rays of two different sizes. In addition, larger rays were comm.only 4 to 10 seriate. This wood density was $0.46 \mathrm{~g} / \mathrm{cm}^{3}$. Examination of the metallic parts of the rifle and the ammunition pouch showed micro cracks and pitting corrosion spreading on the surface. These cracks were a result of chemical reactions between iron surface and corrosion factors in the burial environment and museum store. Metallographic examinations also, showed that the metallic parts of both objects suffered from deterioration aspects, e.g. pitting surface, micro cracks and grieve corrosion. Furthermore, the metal artifacts' microstructure provides a lot of information about the quality of the manufacturing material and the tec- hnology of fabrication. Unfortunately, accessing such information usually requires an invasive intervention of the artifact. A small fragment is detached from the artifact. It is then mounted as a cross section by an embedding procedure. Finally, it is observed under a metallographic microscope. However, this method is not always acceptable. $X$ - $R$ Fluorescence analysis of the rifle and the cover of the ammunition pouch illustrated that the percentage of iron was very high (93.31 $\%)$ and oxygen was low (6.69\%). This means that the metal was in a good state and the layer of corrosion was very thin. Within the same context, XRD diffraction analysis patterns showed that corrosion composition of the metallic parts of the rifle and ammunition pouch mainly consisted of Tephroite (Manganese Silicate $\left(\mathrm{Mn}_{2} \mathrm{SiO}_{4}\right)$, a small amount of Quartz $\left(\mathrm{SiO}_{2}\right)$, and traces of Potassium, Iron, Hydrogen, Phosphate, and Hydrate (K Fe $\left.\mathrm{H}_{14}\left(\mathrm{PO}_{4}\right)_{8} \cdot 4 \mathrm{H}_{2} \mathrm{O}\right)$. SEM micrograph of wooden part showed that the presence of rust between wood was a result of the reaction between corroded iron, moisture, and wood as hygroscopic and porous material which allows corrosion products to penetrate wood cell and damage the wooden surface. Deterioration spots were a result of natural tendency for most pure metals to return to their more stable, and corroded states. Therefore, metal objects should be protected from environmental conditions and pollutants that motivate corrosion. In some cases, as the metal corrodes, the oxide film forming acts as an insulating barrier slows down the rate of corrosion to an acceptable level. However, when iron corrodes, it does not usually form a protective film. As the iron objects are partially protected from aeration by patches of oxide...etc., certain areas become anodic and others cathodes. In fact, the corroding metal behaves in the presence of an electrolyte, as if it were a set of tiny galvanic cells. Iron continues to corrode until no metal is left, unless some other protective coating is applied 
to protect from other elements. Figure (5-b) showed the microstructure of deterioration spots affected the metal parts through spots. These spots were very tinny because rifle had a good metallic state with some slightly pits in different places. EDX analysis showed that the structure of the horn consisted of (C, O, Na, Mg, Fe, Al, S, Si, Cl, and $\mathrm{K}$ ). Therefore, ( $\mathrm{Fe}$ and $\mathrm{O}$ ) were the elements of rust corrosion, ( $\mathrm{Si}, \mathrm{Al}, \mathrm{Mg}$, and $\mathrm{K}$ ) were the elements of dirt and $(\mathrm{Na}$ and $\mathrm{Cl})$ were the elements of Halite. These results mean that there were iron and dust among the grains of the ammunition pouch. Hence, conservation process of the rifle was conducted. Figure (5-c) of the ammunition pouch, (the horn) showed rust between the pouch grains. The presence of rust was less than those between wood fibers because spaces between horn grains were less than those between wood fibers. So, the percentage of absorbing rust was lower. This rust wrenches the horn surface and plays a role of the accelerated factor to change air pollution gases to diluted acids which destroy horn as an organic material.

\section{Conclusion}

Laboratory study and treatment of the composite object shows that the Ottoman rifle composed of wood, iron, copper, and an animal horn. The muzzle of the rifle was made of archaeological iron; there were wires of copper in the rifle for tying some parts. Light microscope demonstrated that there were two kinds of wood over the metal parts; Tamarix and Syacamor. Metallographic investigation shows many cracks on the metal surfaces and on the animal horn. XRD showed the presence of Tephroite (Manganese Silicate $\mathrm{Mn}_{2} \mathrm{SiO}_{4}$ ), Quartez $\left(\mathrm{SiO}_{2}\right)$ and Potassium Iron Hydrogen Phosphate Hydrate $\left(\mathrm{K} \mathrm{Fe} \mathrm{H}_{14}\left(\mathrm{PO}_{4}\right)_{8} .4 \mathrm{H}_{2} \mathrm{O}\right)$. XRF demonstrates the presence of: (Fe, Si, $\mathrm{Mn}, \mathrm{Sn}, \mathrm{Zn}, \mathrm{AS}, \mathrm{O})$ in iron parts. SEM Micrograph of rifle wood and ammunition pouch (horn) showed presence of rust between wood fibers and horn grains. Where, these micrographs demonstrated that, they have a good metallic state with some slight pits in different places. EDX result demonstrates the structure of the horn was (C, O, Na, Mg, Fe, Al, S, Si, Cl, K). Mechanical cleaning was applied on the rifle before separation of organic parts. Chemical cleaning was occurred out on organic parts (wood and Horne) using mixture of (Alcohol- Toluene) (1:1). Consolidation process applied on organic parts using Regalerz $10945 \%$ in toluene. The surface covered with thin layer consisted of $2 \%$ Regalarz in Toluene as surface coating. The use of chemical treatment here is acceptable when the texture of the corrosion does not allow mechanical cleaning. The treatment of metal was beginning with Covering the iron parts of the rifle and the cover of the storage box with a cotton soaking in (5\% solution of Citric Acid mixed with 1 $\%$ Thiourea) and $2 \%$ solution of Sodium Hydroxide ( $\mathrm{NaOH}$ ) to equilibrate the Acidic condition from the last step. Finally, this procedure was followed by washing these parts with deionized water. Repeated washing with hot deionized water to ensure flushing capillaries to remove any chemical residues. Drying with soft and clean cloth. Coating the rifle and the storage with $3 \%$ solution of Benzotriazole (BTA) soluble in Ethanol.

\section{References}

[1] Cox, S., (2008). Enfield rifles the composite conservation of out American civil war heritage, M.Sc., Anthropology, dept., Faculty of Sciences, Texas Univ., USA,

[2] Eaton, R. \& Hale, M., (1993). Wood decay, Chapman, London.

[3] Sjostrom, E., (1993). Wood chemistry fundamental and applications, Academic Press, INC, NY.

[4] Goodyear, F., (1971). Archaeological site science, American Elsevier Pub. Co, London.
[5] Wagner, D. \& Dakoronia, F., (1997). Soil archive classification, Metals, Vol. 95, pp: 21-27

[6] Mohamed, M., (2010). Scientific study for treatment and conservation of archaeological iron artifacts, applied on a selected object from Tell-El Farama, North Sinai, Egypt, in: Amer, W. \& Nour El Dine, A. (eds.) $I^{\text {st }}$ Int. Conf. on Ancient Egyptian Science, Science Heritage Center, Cairo Univ., pp: 359-371. 
[7] Scharff, W. \& Huesmann, I., (1997). Accelerated decay of metal soil finds due to soil pollution, Metals, Vol. 95, pp: 17-20.

[8] Yangsook, K. \& Istvan, S., (2003). Cleaning of corroded iron artifacts using pulsed TEA $\mathrm{CO}_{2-}$ and Nd: YAGlasers, J. of Cultural Heritage, Vol. 4, pp: 129-133.

[9] Williams, A. (2003). The knight and the blast furnace, A history of the metallurgy of armour in the middle ages and the early modern period, Brill, Leiden, Netherlands.

[10] Vella, D., Degrigny C., Grech M., \& Williams A., (2004). Metallurgy of armour exhibited at the palace Armoury, Valletta, Malta, Ashton, J. \& Hallam, D. (eds.) ICOM-CC Metal, Canberra, pp: $24-29$

[11] Reguer, S., Dillmann, P., Mirambet, F., Susini, J. \& Lagarde, P., (2006). Investigation of $\mathrm{Cl}$ corrosion products of iron archaeological artifacts using microfocused synchrotron X-ray absorption spectroscopy, Appl. Phys. Vol. A 83, pp: 189-193.
[12] Fahn, A., Werker, E. \& Baas, P., (1986). Wood anatomy and identification for Israel and adjacent Regions, Israel Academy of Sciences and Humanities, Jerusalem.

[13] Alfonso, V., Paulo, S. \& Baas, P., (1989). Iawa list of microscopic features for hard wood identification, Rijksherbarium, Leiden, Netherland

[14] Crivellaro, A. \& Schwingruber, F., (2013). Atlas of wood, bark and pith anatomy of Eastern Mediterranean trees and shrubs, Springer, Berlin.

[15] Shan, L., Lens, F., Espino, S., Karimi, Z., Klepsch, H., Schmitt, M., Schuldt, B. \& Jansen, S., (2016). Intervessel pit membrane thickness as a key determinant of embolism resistance in Angiosperm Xylem, IAWAI, Vol.37 (2), pp: 152-171.

[16] Bräuning A., Deridder, M., Zafirov, N., González,I., Dimitrov, D. \& Gärtner, H., (2016). Tree-ring features indicators of extreme event impacts, IAWAI, Vol.37 (2), pp: 206-231. 